\title{
LITERASI UANG ELEKTRONIK DI KALANGAN MAHASISWA
}

\section{Puji Lestari}

Dosen Institut Pesantren Mathali'ul Falah Pati

E-mail: puji@ipmafa.ac.id

\author{
Neni Nofriantika \\ Alumnus Institut Pesantren Mathali'ul Falah Pati \\ Emailn9nofriant@gmail.com
}

\begin{abstract}
Electronic money or e-money as a means of non-cash payments (electronic payment), is now interested in Indonesian society. Institut Pesantren Mathali' ul Falah (IPMAFA) is a university that has more than 200 students who studied economics focus in particular knowledge of banking Shari'ah. Despite being in the city with minimal transport facilities-based computer line, but the reach of internet facilities were adequate and modern minimarkets nearby, prompting researchers to determine the level of understanding and use of electronic money among the college students. Data collected through interviews with 21 respondents representing 10\% students of Islamic banking. By using data analysis techniques Miles and Huberman researchers succeeded in preparing the conclusions of this study. Based on the analysis and discussion, the study concluded that the level of knowledge of students of the Institut Pesantren Mathali'ul Falah regarding electronic money based on the theory Personal Capability Maturity Model (P-CMM), these figures are still at the stage where an individual ever had an experience once or twice, and considers e-payment technology is an essential component for achieving the desire and troubleshooting. While the level of use of electronic money mostly students of the Institute Pesantren Mathali'ul Falah is at a level where an individual has repeatedly using e-payment technology to belp with daily activities and has had a recurrence pattern in its use. This means that not all students get to know and use electronic money as a means of non-cash payments.
\end{abstract}

Keywords: Literacy, Electronic Money, Bank Indonesia Regulation.

\section{Abstrak}

Uang elektronik atau e-money merupakan pembayaran non tunai (pembayaran elektronik), yang sekarang menarik bagi masyarakat Indonesia. Institut Pesantren Mathali'ul Falah (IPMAFA) adalah lembaga yang memiliki lebih dari 200 mahasiswa yang mana konsen terbadap studi ekonomi terutama di dalam pembelajaran perbankan syariah. Meskipun menjadi kota dengan dasar fasilitas trasportasi minimal computer line tetapi jangkauan fasilitas internet yang memadai dan dekatnya pasar-pasar modern, para peneliti mendorong keputusan pada tingkat pemahaman dan penggunaan uang elektronik di antara mahasiswa. Pengumpulan data disiapkan dengan 21 partisipan mewakili 10 persen dari mahasiswa perbankan syariah. Analisis data menggunakan teknik dari peneliti Miles dan Huberman yang berhasil dalam mempersiapkan akbir studi ini. Dasar dari diskusi dan analisis studi ini terdapat bahwa tingkat pengetabuan mahasiswa di Institut Pesantren Mathali'ul Falah mengenai dasar nang elektronik pada tokob-tokoh teori Personal Capability Maturity Model (P-CMM) ini, masib ada pada bagian di mana seorang individu sesungguhnya memiliki pengalaman sekali atau dua kali dan mempertimbangkan teknologi pembayaran elektronik sebagai bagian mendasar pemecahan masalah dan keinginan kuat menuju kemajuan. Ketika tingkat penggunaan uang elektronik banyak dilakukan oleh mahasiswa 
Institut Pesantren Mathali'ul Falah pada tingkat di mana individu memiliki pengulangan penggunaan teknologi pembayaran elektronik untuk membantu aktivitas harian dan memiliki satu pola berulang di dalam penggunaannya. Ini berarti bahwa tidak semua mahasiswa mengetabui dan menggunakan uang elektronik sama artinya dengan pembayaran non tunai.

Kata Kunci: Literasi, Uang Elektronik, Peraturan Bank Indonesia.

\section{A. Pendahuluan}

Uang elektronik dijelaskan Bank Indonesia dalam Peraturan Bank Indonesia No.16/8/PBI/2014 bahwa yang dimaksud uang elektronik atau electronic money adalah alat pembayaran yang memenuhi unsur-unsur diterbitkan atas dasar nilai uang yang disetor terlebih dahulu kepada penerbit, nilai uang disimpan secara elektronik dalam media server atau chip, digunakan sebagai alat pembayaran kepada pedagang yang bukan merupakan penerbit uang elektronik tersebut, dan nilai uang elektronik yang dikelola oleh penerbit bukan merupakan simpanan sebagaimana dimaksud dalam undang-undang yang mengatur mengenai perbankan.

Sebagai jenis transaksi pembayaran baru yang modern, disahkannya produk uang elektronik menjadikan peluang bagi lembaga keuangan baik bank maupun non bank untuk menerapkan aplikasi uang elektronik. Mengingat perkembangan teknologi informasi yang semakin pesat serta tumbuhnya kebutuhan masyarakat akan fasilitas pelayanan yang cepat, semakin menjadikan aplikasi uang elektronik akan diminati dan menjadi peluang yang besar bagi lembaga-lembaga tersebut. Seperti yang diungkap Direktur Kepala Program Elektronifikasi dan Keuangan Inklusif Bank Indonesia, Pungky P. Purnomor pada Kamis (15/10/2015), "Menurut data yang dirilis Bank Indonesia, geliat e-commerce dalam setahun terakhir ikut mendorong transaksi penggunaan uang berbasis elektronik atau e-money hingga dua kali lipat'.

Meski penggunaan uang elektronik masih terbatas, namun aplikasi uang elektronik menjadi salah satu strategi Bank Indonesia dalam mensukseskan Gerakan Nasional Non

\footnotetext{
${ }^{1}$ http://inet.detik.com/read/2015/10/15/155 628/3044838/328/geliat-e-commerce-ikutgenjot-e-money-200 diakses tanggal 21 Maret 2016 pukul 14.21 WIB.
} 
Tunai (GNNT) dengan tujuan membentuk suatu komunitas atau masyarakat yang lebih menggunakan instrumen non tunai (LCS/Less Cash Society) dalam transaksi ekonominya. ${ }^{2}$

Mengingat peningkatan penggunaan uang elektronik semakin signifikan serta meningkatnya minat masyarakat bertransaksi e-commerse maka penguasaan pemahaman serta keterampilan bertransaksi dengan uang elektronik menjadi tantangan mahasiswa perbankan syariah secara khusus. Dengan bertambahnya fungsi uang elektronik dan meluasnya jangkauan penggunaan dan fasilitas uang elektronik, dimungkinkan waktu yang akan datang masyarakat akan beralih menggunakan uang elektronik sebagai alat pembayaran utama.

Untuk menghadapi kemajuan teknologi di dunia perbankan tersebut, mahasiswa perbankan syariah dituntut untuk mempersiapkan diri dengan meningkatkan literasinya tentang uang elektronik. Salah satu perguruan tinggi swasta yang memiliki program studi perbankan syariah ialah Institut Pesantren Mathali'ul Falah (IPMAFA) Pati. Untuk mempersiapkan ekonom muda menghadapi tantangan ekonomi dimasa mendatang di bidang perbankan khususnya perbankan syariah di IPMAFA, penelitian ini ingin mengetahui bagaimana gambaran tingkat pengetahuan dan penggunaan uang elektronik oleh mahasiswa IPMAFA.

\section{B. Metode Penelitian}

\section{Jenis Penelitian}

Jenis penelitian yang digunakan dalam penelitian ini adalah metode field research. Dalam penelitian lapangan, peneliti akan terjun langsung di lokasi penelitian untuk mengumpulkan data. Menurut Sugiyono metode penelitian kualitatif adalah metode penelitian yang berlandaskan pada filsafat postpositivisme, digunakan untuk meneliti pada kondisi objek yang alamiah, dimana peneliti adalah sebagai instrumen kunci, teknik pengumpulan data dilakukan secara triangulasi (gabungan), analisis data bersifat

\footnotetext{
${ }^{2}$ Siaran Pers BI No. 16/58/DKOM
} 
induktif/kualitatif, dan hasil penelitian kualitatif lebih menekankan makna daripada generalisasi. $^{3}$

Teknik pengumpulan data bersifat triangulasi yaitu menggunakan berbagai teknik pengumpulan data secara gabungan atau simultan dimaksudkan untuk dapat memahami lebih luas dan mendalam terhadap situasi sosial yang kompleks dan dinamis. ${ }^{4}$ Dalam penelitian kualitatif, analisis data yang dilakukan bersifat induktif berdasarkan fakta-fakta yang ditemukan di lapangan dan kemudian dikonstruksikan menjadi hipotesis atau teori. ${ }^{5}$

\section{Desain Penelitian}

Menurut Nachmias dalam Robert Yin mendeskripsikan desain penelitian sebagai suatu rencana yang peneliti mencoba menyusun desain penelitian dalam 4 tahap, yaitu: mengidentifikasi topik penelitian, melakukan tinjauan pustaka dan lapangan, pengumpulan data, analisis data serta interpretasi dan diseminasi hasil sebagai tahap merangkum dan menjelaskan tema-tema dan pola-pola sebagai hasil penelitian dalam bentuk naratif. ${ }^{6}$

Teknik pengambilan sampel dalam penelitian ini menggunakan teknik purposive sampling. Teknik ini merupakan teknik pengambilan sampel sumber data dengan pertimbangan tertentu. ${ }^{7}$ Pertimbangan yang dimaksud adalah sampel dengan kriteria tertentu yang termasuk dalam subjek penelitian.

Sumber penelitian yang dibutuhkan peneliti adalah sumber primer yaitu sumber data yang langsung memberikan data kepada pengumpul data. ${ }^{8}$ Instrumen pendukung dalam penelitian ini berupa panduan wawancara berupa pertanyaan-pertanyaan terstruktur yang sifatnya terbuka.

Pertanyaan-pertanyaan dalam panduan wawancara disusun oleh peneliti berdasarkan prosedur yang sesuai dengan langkah-langkah pengembangan kuesioner. Langkah-langkah yang dimaksud adalah mengembangkan variabel menjadi indikator, dimana indikator

${ }^{3}$ Sugiyono, Metode Penelitian Kuantitatif, Kualitatif, dan R\&D, (Bandung: Alfabeta, 2008) hlm.9.

${ }^{4}$ Sugiyono, Metode Penelitian Kuantitatif, Kualitatif, dan R\&D..., hlm.8.

${ }^{5}$ Sugiyono, Metode Penelitian Kuantitatif, Kualitatif, dan Re D..., hlm.9.

${ }^{6}$ Robert K. Yin, Studi Kasus:Desain dan Metode, (Jakarta: PT. Rajagrafindo Persada, 2009) hlm.28.

${ }^{7}$ Robert K. Yin, Studi Kasus:Desain dan Metode..., hlm. 218-219.

${ }^{8}$ Sugiyono, Metode Penelitian..., hlm. 225. 
selanjutnya dibagi menjadi beberapa deskriptor yang kemudian setiap deskriptor dikembangkan menjadi sebuah pertanyaan.

\section{Teknik Analisis Data}

Menurut Miles dan Huberman ada tiga macam kegiatan dalam analisis data kualitatif, yaitu: Reduksi Data merujuk pada proses pemilihan, pemfokusan, penyederhanaan, abstraksi, dan pentransformatif "data mentah" yang terjadi dalam catatan-catatan lapangan tertulis. Sebagaimana kita ketahui, reduksi data terjadi secara kontinu melalui kehidupan suatu proyek yang diorientasikan secara kualitatif.' Tahap kedua ialah model Data (Data Display) yaitu mendefinisikan "model" sebagai suatu kumpulan informasi yang tersusun yang membolehkan pendeskripsian kesimpulan dan pengambilan tindakan. ${ }^{10}$ Tahap terakhir yakni penarikan / verifikasi kesimpulan.

\section{Hasil Penelitian Literasi Uang Elektronik di Kalangan Mahasiswa}

\section{Tingkat Pengetahuan Dasar}

Temuan pertama berkenaan dengan pengertian atau gambaran uang elektronik menurut mahasiswa program studi Perbankan Syariah. Dari 21 jawaban informan, 3 diantaranya atau 14\% sampel menjawab tidak tahu. Dari 18 jawaban lainnya peneliti membagi gambaran uang elektronik menurut mahasiswa menjadi empat kategori. Kategori pertama, gambaran mahasiswa program studi Perbankan Syariah tentang uang elektronik berdasarkan sifat penyimpanannya ialah uang yang secara fisik tidak nyata akan tetapi dapat digunakan untuk bertransaksi dengan menggunakan media elektronik.

Kategori kedua, peneliti menyimpulkan gambaran mahasiswa program studi Perbankan Syariah tentang uang elektronik berdasarkan penyerupaan dengan produk lain secara umum. Penyerupaan dengan produk lain artinya bukan berasal dari petunjuk atau informasi khusus, melainkan informasi yang diolah berdasarkan studi kasus umum. Dalam hal ini mahasiswa program studi Perbankan Syariah menganggap bahwa uang elektronik adalah uang yang diakses melalui mesin ATM. Kategori ketiga, gambaran mahasiswa

\footnotetext{
${ }_{9}^{9}$ Sugiyono, Metode Penelitian..., hlm. 129.

${ }^{10}$ Sugiyono, Metode Penelitian..., hlm 131.
} 
program studi Perbankan Syar'ah tentang uang elektronik berdasarkan manfaatnya. Sebanyak $10 \%$ dari sampel penelitian mendefisinikan uang elektronik berdasarkan kemanfaatannya dalam mempermudah sebuah transaksi.

Kategori keempat merupakan kategori lain-lain yang tidak termasuk dalam ketiga kategori sebelumnya. Kategori definisi lain-lain ditempati sebanyak 14\% dari jumlah informan. Kategori lain-lain merupakan ruang bagi jawaban yang bersifat variatif yakni jawaban yang tidak dapat digolongkan sendiri hingga jawaban yang tidak mampu menggambar definisi uang elektronik.

Temuan kedua berkenan dengan pengetahuan mahasiswa program studi Perbankan Syariah mengenai latar belakang disahkannya alat pembayaran uang elektronik. Sebanyak 92\% mahasiswa yang menjadi informan sepakat bahwa latar belakang disahkannya alat pembayaran uang elektronik adalah bertujuan untuk mempermudah transaksi pembayaran. Sekitar 4\% informan mengaku tidak tahu latar belakang diterbitkannya uang elektronik di Indonesia. Sisanya sebanyak 4\% disediakan sebagai jawaban lain-lain.

Berlainan dengan temuan sebelumnya, temuan ketiga berkenaan dengan mulai disahkannya uang elektronik di Indonesia oleh bank sentral. Peneliti mendapati 88\% informan sepakat menjawab tidak tahu sejak kapan uang elektronik mulai disahkan di Indonesia. Meskipun angka tersebut mengecewakan, namun salah satu informan nomor 17 menjawab dengan benar, "Kalau saya sib tahunya sejak 2009 mbak,",11 meskipun jawaban tersebut mengindikasikan ia tidak yakin betul. Sedangkan $8 \%$ lainnya dalam kategori lain-lain yang tidak dapat menyebutkan jawaban dengan benar.

Temuan selanjutnya yakni temuan keempat berkenaan dengan pengetahuan mahasiswa program studi Perbankan Syariah mengenai tempat-tempat dimana pengguna uang elektronik dapat bertransaksi. Dalam temuan ini peneliti mengklasifikasikan

11 Wawancara pada 27 Mei 2016 pukul 11.51 WIB 
pengetahuan mahasiswa program studi Perbankan Syariah mengenai tempat transaksi uang elektronik dalam empat kategori.

Kategori pertama, yakni kategori dengan jumlah informan terbanyak atau sekitar $52 \%$ yaitu pengetahuan mahasiswa program studi Perbankan Syariah mengenai penggunaan uang elektronik berdasarkan tempat transaksi. Kategori ini menilai uang elektronik dapat digunakan di pusat perbelanjaan yang memiliki mesin pembaca uang elektronik dan dapat digunakan di bank serta fasilitas-fasilitas yang dimilikinya, seperti ATM.

Kategori kedua, sebanyak 17\% informan menilai transaksi uang elektronik hanya dapat dilakukan melalui media elektronik yang terhubung dengan jaringan (internet). Peneliti mengklasifikasikan kategori kedua sebagai pengetahuan mahasiswa program studi Perbankan Syariah mengenai penggunaan uang elektronik berdasarkan media transaksi. Temuan kelima berkenaan dengan pengetahuan mahasiswa program studi Perbankan Syariah mengenai pihak-pihak yang mengelola uang elektronik.

Dari 21 jawaban informan, sebanyak 6 diantaranya mengaku tidak tahu siapa saja pihak yang yang mengelola uang elektronik. Sisa 15 jawaban peneliti mengklasifikasikan empat pihak menurut pengetahuan mahasiswa Program Studi Perbankan Syariah yang terkait dalam pengelolaan uang elektronik. Keempat kategori pihak tersebut adalah pihak pengguna, pihak bank dan lembaga keuangan lain, pihak perusahaan (penerbit uang elektronik) dan pihak lain-lain yang disebutkan. Sebanyak 36\% jawaban setuju pihak yang paling berperan dalam pengelolaan uang elektronik adalah pihak bank dan lembaga keuangan lain.

Pihak selanjutnya tentu saja pengguna uang elektronik dengan prosentase jawaban sebesar 30\%. Sedangkan 24\% jawaban lainnya menilai perusahaan-perusahaan yang menggunakan uang elektronik sebagai salah satu fasilitas transaksi juga termasuk dalam pihak yang mengelola uang elektronik. Sisa jawaban sebanyak 10\% termasuk dalam kategori pihak lain-lain Temuan keenam ini berkenaan pengetahuan mahasiswa program studi Perbankan Syariah mengenai cara bertransaksi menggunakan uang elektronik. 
Dari 21 informan 3 diantaranya mengaku tidak tahu bagaimana cara bertransaksi menggunakan uang elektronik. Berdasarkan 18 reponden yang tersisa, peneliti mengklasifikasikan cara bertransaksi menggunakan uang elektronik berdasarkan pengetahuan mahasiswa program studi Perbankan Syariah ke dalam empat kategori.

Kategori pertama mendapatkan 55\% jawaban informan. Menurut pengetahuan mahasiswa program studi Perbankan Syariah, cara bertransaksi dengan menggunakan uang elektronik adalah dengan memasukkan, menggesek ataupun menempel kartu uang elektronik yang disertai dengan konfirmasi kode pin kartu. Penilaian ini tidak sepenuhnya benar, karena pada dasarnya uang elektronik berbentuk kartu maupun chip secara opersionalnya hanya perlu menempel atau menggesek kartu pada alat atau mesin pembaca sama seperti APMK pada umumnya.

Meskipun begitu, pada kategori kedua ini peneliti tetap optimis karena 1 diantara 21 informan menjawab dengan benar. Seperti jawaban dari salah satu informan nomor 14, “...kalo yang kartu ATM pakai nomer pin, kalo yang kartu Indomart atau Alfamart Card nggak pakai pin langsung digesek mbak kasirnya". ${ }^{12}$ Dari pernyataan tersebut mengindikasikan informan telah memiliki uang elektronik namun tetap menganggap bahwa kartu kredit termasuk dalam jenis uang elektronik.

Pada kategori ketiga sebanyak 15\% jawaban informan mengindikasikan cara bertransaksi menggunakan uang elektronik hanya dapat dilakukan melalui media elektronik yang terdapat aplikasi uang elektronik, selain itu juga harus terhubung dengan jaringan (internet). Sedangkan 10\% jawaban informan termasuk dalam kategori lain-lain.

\section{a. Pengetahuan Atribut Produk}

Indikator variabel pengetahuan yang kedua adalah pengetahuan tentang atribut produk. Pengetahuan tentang atribut produk dinilai berdasarkan pengetahuan subjek penelitian mengenai ciri fisik dan karakteristik sifat produk. Untuk melihat suatu ciri atau karakter tentu saja melalui perbandingan. Sehingga dimunculkan pertanyaan yang mampu

\footnotetext{
12 Wawancara pada 27 Mei 2016 pukul 09.40 WIB.
} 
menggali informasi dari informan mengenai perbandingan uang elektronik dengan jenis uang lainnya yakni uang kartal dan uang giral. Berdasarkan langkah tersebut, peneliti berhasil merangkum dua temuan sebagai hasil penelitian pengetahuan atribut produk.

Temuan pertama berkenaan dengan pandangan mahasiswa program studi Perbankan Syariah mengenai perbedaan ciri fisik uang elektronik dengan jenis uang lainnya. Berdasarkan 21 jawaban informan, peneliti mengklasifikasikan jawaban tersebut ke dalam 4 kategori pengetahuan mahasiswa Program Studi Perbankan Syariah mengenai atribut produk uang elektronik. Kategori pertama, 7 dari 21 informan menganggap perbedaan uang elektronik berdasarkan pada nilai yang terlihat secara fisik untuk jenis uang giral dan uang kartal sedangkan uang elektronik nilai uangnya secara fisik tidak terlihat. Dalam hal ini diketahui bahwa menurut pengetahuan mahasiswa Program Studi Perbankan Syariah untuk melihat nilai uang pada uang elektronik harus menggunakan media elektronik, sedangkan untuk nilai uang pada uang tunai tidak perlu melalui perantara atau media apapun.

Hampir setara dengan kategori pertama, 6 di antara 21 informan dikelompokkan dalam kategori kedua yang menganggap perbedaan ciri fisik uang elektronik dengan jenis uang lainnya adalah uang elektronik dibuat dalam bentuk kartu, chip dan server sedangkan jenis uang lainnya terbuat dari kertas dan logam. Kategori selanjutnya terdapat 4 informan yang mengaku tidak tahu perbedaan bentuk uang elektronik dengan jenis uang lainnya. Pada kategori ketiga dan keempat tersisa 8 informan yang masing-masing 4 informan menjawab tidak tahu perbedaan ciri fisik uang elektronik dengan jenis uang lainnya, dan 4 informan lainnya termasuk dalam kategori jawaban lain-lain.

Temuan kedua berkenaan dengan karakteristik sifat produk uang elektronik. Berdasarkan 21 jawaban informan yang terkumpul, peneliti membagi pengetahuan mahasiswa program studi Perbankan Syariah mengenai perbedaan uang elektronik dengan jenis uang lainnya berdasarkan penggunaannya ke dalam empat kategori. Kategori pertama adalah kelompok jawaban-jawaban informan sebanyak 11 dari 21 jawaban yang mengarah pada kelebihan dan kelemahan uang elektronik dibandingkan jenis uang lainnya. Kelebihan uang elektronik dibandingkan jenis uang lainnya diantaranya lebih praktis, mudah dan transaksi dapat dilakukan kapan saja. Sedangkan 
kelemahan uang elektronik dibandingkan jenis uang lainnya adalah tingkat penggunaan yang masih terbatas dan bagi orang-orang yang gagap teknologi akan susah menggunakannya.

Peneliti memberikan kategori pertama sebagai pandangan mahasiswa program studi Perbankan Syariahdalam membedakan penggunaan uang elektronik dengan jenis uang lainnya berdasarkan sifat produk uang elektronik itu sendiri. Kategori kedua merupakan pandangan mahasiswa program studi Perbankan Syariah tentang perbedaan uang elektronik dengan jenis uang lainnya berdasarkan cara penggunaan.

Diketahui 7 dari 21 informan menjawab perbedaan uang elektronik dengan jenis uang lainnya jika bertransaksi dengan uang elektronik perlu menggunakan media elektronik, sedangkan transaksi uang kartal dilakukan secara langsung. Empat informan lainnya dalam kategori ketiga yakni kategori lain-lain. Sedangkan 3 informan lainnya dalam kategori keempat menjawab tidak tahu.

\section{b. Pengetahuan Manfaat Produk}

Pada indikator pengetahuan tentang manfaat produk, terbagi dalam dua faktor yakni faktor manfaat fungsional dan faktor manfaat emosional. Faktor manfaat fungsional ialah faktor kemanfaatan yang dirasakan berdasarkan fungsi atau kegunaan produk. Sedangkan faktor manfaat emosional adalah faktor kemanfaatan yang dirasakan di luar fungsi atau kegunaan produk itu sendiri, yakni kemanfaat yang muncul berdasarkan pengaruh pola pikir pengguna produk. Berdasarkan pengumpulan data yang berasal dari pertanyaan kedua faktor tersebut, peneliti memperoleh dua temuan yang masing-masing memiliki kategori khusus. Temuan pertama berkenaan dengan pengetahuan mahasiswa program studi Perbankan Syariah mengenai transaksi-transaksi yang dapat menggunakan uang elektronik sebagai alat pembayarannya.

Berdasarkan 37 jawaban yang bervariatif dari 21 informan, peneliti mengklasifikasikan empat kategori jenis transaksi menurut pengetahuan mahasiswa program studi Perbankan Syariah yang dapat menggunakan uang elektronik sebagai alat pembayaran. Keempat kategori jenis transaksi tersebut adalah transaksi belanja baik 
online maupun langsung, macam-macam transaksi pembayaran tagihan, transfer uang dan transaksi- transaksi lain yang tidak termasuk dalam ketiga kategori sebelumnya.

Sebanyak 60\% jawaban sepakat transaksi belanja baik secara online maupun langsung merupakan transaksi yang paling sering menggunakan uang elektronik sebagai alat pembayarannya. Transaksi selanjutnya yang paling sering disebut informan untuk menggunakan uang elektronik ialah transfer dana dengan prosentase jawaban sebesar 18 persen. Temuan kedua berkenaan dengan pandangan mahasiswa program studi Perbankan Syariah mengenai manfaat emosional jika menggunakan uang elektronik sebagai alat pembayaran sehari-hari. Poin dalam faktor kedua ini adalah anggapan informan tentang orang yang menggunakan uang elektronik adalah termasuk orang yang bergaya hidup modern. Sebanyak 76\% informan menjawab "iya" atau menganggap bahwa orang yang menggunakan uang elektronik adalah termasuk orang yang bergaya hidup modern.

Ada pula informan yang tidak sependapat, kategori kedua ini menolak anggapan bahwa orang yang menggunakan uang elektronik merupakan orang yang bergaya hidup modern. Sebanyak 4 dari 21 informan merupakan kelompok kategori ini. Karena menurut informan pada kategori ini, penggunaan uang elektronik sudah dianggap sebagai sebuah kebutuhan. Sedangkan 1 diantara 21 informan sebagai kategori ketiga menyatakan ragu-ragu jika orang yang menggunakan uang elektronik merasa bergaya hidup modern.

\section{c. Pengetahuan Nilai Kepuasan Produk}

Pengetahuan tentang nilai kepuasan produk dinilai berdasarkan pendapat subyek penelitian mengenai nilai lebih yang didapatkan jika menggunakan uang elektronik. Faktor nilai lebih itu berdasarkan pengaruh penggunaan produk uang elektronik terhadap faktor produktivitas dan efektivitas kegiatan sehari-hari pengguna. Faktor nilai kepuasan produktivitas Adalah adanya peningkatan hasil kegiatan sehari-hari

Ketika menggunakan uang elektronik sebagai alat pembayaran dibandingkan tidak menggunakan. Sedangkan faktor nilai kepuasan efektifitas adalah adanya peningkatan dalam 
usaha pemanfaatan waktu secara optimal dalam kegiatan sehari-hari ketika menggunakan uang elektronik sebagai alat pembayaran dibandingkan tidak menggunakan. Berdasarkan pengumpulan data yang berasal dari pertanyaan kedua faktor tersebut, peneliti memperoleh dua temuan yang masing-masing memiliki kategori khusus. Temuan pertama berkenaan dengan pandangan mahasiswa program studi Perbankan Syariah mengenai nilai lebih uang elektronik yang mampu meningkatkan produktifitas kegiatan sehari-hari para penggunanya.

Berdasarkan data yang terkumpul dari 21 informan, peneliti mengklasifikasikan temuan faktor produktifitas dalam tiga kategori. Kategori pertama mengumpulkan 11 dari 21 jawaban informan menjawab "Iya". Artinya lebih dari 50\% informan menyatakan sepakat bahwa dengan menggunakan uang elektronik sebagai alat pembayaran mampu meningkatkan produktifitas kegiatan sehari-hari. Namun kategori kedua mendapati 8 dari 21 informan atau hampir 40\% informan meragukan jika dengan menggunakan uang elektronik sebagai alat pembayaran mampu meningkatkan produktivitas kegiatan seharihari.

Temuan kedua peneliti mendapati hampir 100\% informan sepakat bahwa dengan menggunakan uang elektronik sebagai alat pembayaran mampu meningkatkan efisiensi waktu sehingga kegiatan sehari-hari pengguna uang elektronik lebih efektif. Seluruh informan optimis menjawab "Iya". Setelah peneliti menganalisis data penelitian ke dalam beberapa konsep, akhirnya peneliti dapat menjawab pertanyaan penelitian pertama ke dalam deskripsi verifikasi kesimpulan berikut ini: Sebanyak 21 informan penelitian telah mewakili 10\% jumlah mahasiswa Institut Pesantren Mathali'ul Falah jurusan Syariah dan Ekonomi Islam khususnya program studi Perbankan Syariah, mulai dari tingkatan semester II hingga semester VIII.

Meskipun penelitian ini tidak bermaksud menggeneralisasikan hasil penelitian akan tetapi diharapkan mampu memberi gambaran kondisi yang ada. Meskipun hasil telaah konsep para informan bahwa definisi uang elektronik, pandangan bahwa uang elektronik harus dioperasikan menggunakan layanan jaringan internet maupun anggapan bahwa semua kartu yang dioperasikan menggunakan ATM adalah uang elektronik sehingga belum 
sepenuhnya sesuai dengan definisi uang elektronik menurut Bank Indonesia, akan tetapi berdasarkan konsep definisi tersebut dapat diketahui sejauh mana pengetahuan uang elektronik menurut para informan.

Dari fakta itu dengan mengacu pada teori Personal Capability Maturity Model (PCMM), dimana ICT Literacy seorang individu dapat dikategorikan atas lima tingkat maka secara umum tingkat pengetahuan mahasiswa Institut Pesantren Mathali'ul Falah mengenai uang elektronik masih berada pada tingkat 1, yaitu seorang individu pernah memiliki pengalaman satu dua kali, dimana teknologi e-payment merupakan sebuah komponen penting untuk pencapaian keinginan dan pemecahan masalah.

\section{Tingkat Keterampilan}

Indikator kepemilikan produk terdiri dari tiga deskriptor yakni jenis produk, merek produk dan jenis transaksi. Ketiga deskriptor tersebut perlu ditanyakan agar jawaban informan dapat ditelusuri jenis kepemilikan produk uang elektronik dan bukan kepemilikan jenis uang lain yang dianggap produk uang elektronik. Selain itu dapat dianalisis lebih lanjut jenis uang elektronik yang sering digunakan. Berdasarkan data yang terkumpul dari jawaban-jawaban atas pertanyaan ketiga deskriptor tersebut, peneliti menyusun tiga temuan.

Temuan pertama adalah 19 dari 21 informan tidak memiliki uang elektronik. Sedangkan dua lainnya memiliki uang elektronik dengan jenis uang elektronik yang berbeda. Berdasarkan hasil penelitian berkenaan indikator tingkat keterampilan/pengalaman mahasiswa menggunakan uang elektronik yang telah dipaparkan di atas, peneliti merangkum dua konsep inti hasil penelitian tingkat pengetahuan untuk mempermudah dalam penyusunan verifikasi kesimpulan kemudian. Kedua konsep hasil penelitian tersebut adalah:

1. Konsep tingkat keterampilan dan pengalaman mahasiswa menggunakan uang elektronik ini dirangkum berdasarkan data yang terkumpul dari 2 informan yang memiliki uang elektronik. Konsep keempat menjelaskan bahwa literasi uang elektronik informan terbatas pada jenis uang elektronik yang dimiliki. Kedua informan diwawancara di tempat dan waktu yang berbeda, masing-masing memiliki jenis uang 
elektronik yang berbeda pula. Konsep ini teridentifikasi berdasarkan pernyataan kedua informan ketika menjelaskan cara bertransaksi menggunakan uang elekronik. Informan pertama yang memiliki uang elektronik media server menjelaskan cara bertransaksi menggunakan uang elektronik melalui pernyataan, "Ya kita daftar di aplikasinya (red: produk uang elektronik) pakai e-mail, terus pas belanja online bayarnya pakai uang kita yang sebelumnya sudah kita setor di aplikasi PayPal. Konfirmasi pembayarannya melalui e-mail." "13 Sedangkan Informan kedua yang memiliki uang elektronik media chip dalam kartu menjelaskan cara bertransaksi menggunakan uang elektronik melalui pernyataan, "Caranya kartu (Indomart Card) diisi ulang atau pakai uang di rekening, kartu digesek atau dimasukkan dalam mesin...kalo yang kartu ATM pakai nomer pin, kalo yang kartu Indomart atau Alfamart Card nggak pakai pin langsung digesek mbak kasirnya." 14

2. Selaras dengan konsep pertama, dalam konsep kedua melanjutkan analisis dari data dua informan yang diketahui memiliki uang. elektronik. Dari kedua pertanyaan informan mengenai frekuensi dan jenis penggunaan uang elektronik yang dimiliki, peneliti merangkum konsep kedua sebagai konsep yang menjelaskan bahwa penggunaan uang elektronik kedua informan pada jenis transaksi belanja baik melalui online maupun secara langsung. Selain itu, frekuensi masih terbilang rendah mengingat tidak semua transaksi belanja dapat menggunakan uang elektronik sebagai alat pembayarannya.

\section{Kesimpulan}

Setelah peneliti menganalisis data penelitian ke dalam beberapa konsep, akhirnya peneliti dapat menjawab pertanyaan penelitian kedua ke dalam deskripsi verifikasi kesimpulan berikut ini: Meskipun kesimpulan atas jawaban pertanyaan penelitian kedua mengenai tingkat keterampilan dan pengalaman mahasiswa menggunakan uang elektronik hanya menggambarkan dua informan akan tetapi jumlah ini bisa bertambah jika memang

13 Wawancara pada responden nomor 01 tanggal 24 Mei 2016 pukul 09.44 WIB

14 Wawancara pada responden nomor 14 tanggal 27 Mei 2016 pukul 09.40 WIB 
beberapa mahasiswa yang memiliki uang elektronik tidak menjadi informan dalam penelitian ini.

Terlepas dari itu, adanya mahasiswa yang menggunakan uang elektronik dengan kondisi demografi kota yang kurang mendukung serta kesadaran mahasiswa untuk menggunakan uang elektronik sebagai sebuah kebutuhan, telah menjadi nilai tambah bagi semua pihak. Sehingga dalam hipotesis kerja kedua peneliti dapat menyimpulkan bahwa dengan mengacu Tingkatan literasi TIK, tingkat penggunaan mahasiswa Institut Pesantren Mathali'ul Falah mengenai uang elektronik berada pada tingkat 2, yaitu seorang individu telah berkali-kali menggunakan teknologi e-payment untuk membantu aktivitas sehari-hari dan telah memiliki pola keberulangan dalam penggunaannya.

Kesimpulan penelitian ini dapat dimaknai bahwa respon mahasiswa IPMAFA mengenai kemajuan teknologi di bidang pembayaran non tunai khususnya uang elektronik akan lebih baik lagi jika dikenalkan secara intensif dan mulai menjadikannya sebagai sebuah kebutuhan penunjang dalam kegiatan sehari-hari. Dengan demikian program Gerakan Nasional Non Tunai (GNNT) pemerintah untuk menciptakan masyarakat pengguna pembayaran non tunai (Less Cash Society) dapat segera terwujud. 
PUJI LESTARI dan NENI NOFRIANTIKA

\section{Daftar Pustaka}

Siaran Pers BI No. 16/58/DKOM

Sugiyono, 2008, Metode Penelitian Kuantitatif, Kualitatif, dan R®D, Bandung: Alfabeta.

Robert K. Yin, 2009, Studi Kasus:Desain dan Metode, Jakarta: PT. Rajagrafindo Persada.

Wawancara pada 27 Mei 2016 pukul 11.51 WIB

Wawancara pada 27 Mei 2016 pukul 09.40 WIB.

Wawancara pada responden nomor 01 tanggal 24 Mei 2016 pukul 09.44 WIB

Wawancara pada responden nomor 14 tanggal 27 Mei 2016 pukul 09.40 WIB

Geliat E Commerce Ikut Genjot E Money 2010, http://inet.detik.com/read/2015/10/15/155 628/3044838/328/geliat-e-commerceikut-genjot-e-money-200 diakses tanggal 21 Maret 2016 pukul 14.21 WIB. 